\title{
On trends in nutrient concentration in the northern Wadden Sea of Sylt*
}

\author{
Peter Martens \\ Biologische Anstalt Helgoland, Wattenmeerinstitut List; \\ D-2282 List/Sylt, Bundesrepublik Deutschland
}

\begin{abstract}
The mean values on hydrographical parameters in the Wadden Sea of Sylt taken weekly over a period of seven years $(1975,1976$ and 1984 to 1988) were compared in order to detect trends in concentrations of nutrients or plankton. An increase in $\mathrm{NO}_{2}, \mathrm{NO}_{3}, \mathrm{PO}_{4}$ and $\mathrm{Si}$ could be found in summer. $\mathrm{NH}_{4}$ showed a negative trend. Corresponding with the rising nutrient-level, chlorophyll-a and $\mathrm{pH}$ show a positive trend. Salinity decreased significantly. Changes in $\mathrm{NH}_{4}$ and $\mathrm{NO}_{2}$ were correlated with rainfall.
\end{abstract}

\section{INTRODUCTION}

The northern Wadden Sea of Sylt lies east of the northern part of the island of Sylt; it is separated from other parts of the Wadden Sea by two dams and is connected with the North Sea only by a relatively narrow tidal inlet, the Lister Deep (Fig. 1). Measurements on the biological oceanography of this part of the Wadden Sea have been performed since 1972. Several publications (Hickel, 1980, 1983, 1989; Martens, 1980, 1981, 1982, $1986 \mathrm{a}, 1986 \mathrm{~b})$ deal with the hydrography, phyto- and zooplankton of this area.

Since Radach \& Berg (1986) have shown an increasing positive trend in the nutrient concentration in the German Bight and Hickel (1989) suggests an increase in phosphateconcentration in the northern Wadden Sea of Sylt, a comparison of the values taken over 6 years was carried out to verify trends in various hydrographical parameters.

\section{MATERIALS AND METHODS}

From May 1975 onwards, measurements have been performed twice a week, if possible, (depending on weather conditions), on the following hydrographical parameters (for position of station Lister Ley see Fig. 1):

(1) water temperature (reversing thermometer; $\pm 0.05^{\circ} \mathrm{C}$ )

(2) salinity (Autosal 8400 a Salinometer; $\pm 0.001 \mathrm{~S}$ )

(3) $\mathrm{PO}_{4}$ (after Graßhoff, 1976)

(4) $\mathrm{NH}_{4}, \mathrm{NO}_{2}$ and $\mathrm{NO}_{3}$ (after Graßhoff, 1976)

(5) Si (after Graßhoff, 1976)

- Presented at the VI International Wadden Sea Symposium (Biologische Anstalt Helgoland, Wattenmeerstation Sylt, D-2282 List, FRG, 1-4 November 1988) 


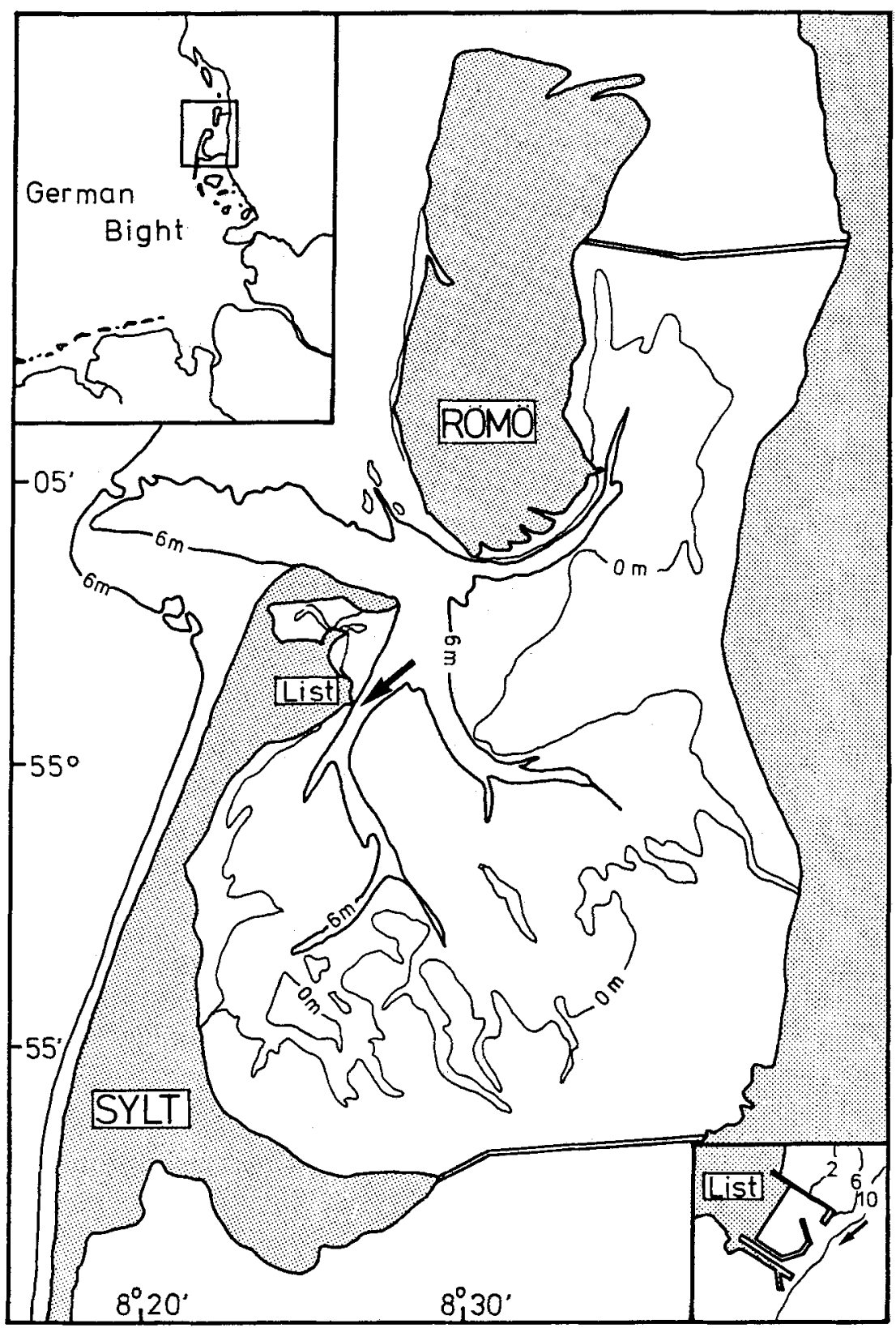

Fig. 1. Map of the northern Wadden Sea of Sylt with the sampling location Lister Ley (see arrow). Depths refer to mean spring low tide. Arrows indicate sampling location 
(6) chlorophyll-a (UNESCO-standard-method)

(7) daily rainfall (Deutscher Wetterdienst, Wetterstation List).

The analyses were carried out on discrete watersamples taken with TPN-watersamplers near the surface. Strong turbulence prevents stratification in these waters (Hickel, 1975; Martens, unpubl. data).

\section{Mathematical procedures}

Between 1975 and 1988, seven years were chosen for statistical analysis where regular measurements from the same station were available (1975, 1976 and 1984-1988). Sets of data were tested for deviation from normal distribution by $\mathrm{Chi}^{2}$-test, $\mathrm{R} / \mathrm{s}$-test and KS-test, and log-transformed when necessary.

Simple regression analyses were performed to show linear trends in the concentration of the parameters measured. To verify significant trends $(\mathrm{P}<0.05)$, partial correlation analyses were performed to ascertain an influence of time on the concentration of the parameters when the tidal influence (temperature and salinity) was eliminated.

As some of the sets of data showed significant deviation from the normal distribution in at least one of the tests used, a Spearman-Rank-correlation was carried out to verify significant findings.

Finally, a stepwise variable selection was performed for all parameters that had shown a significant trend. If, in addition to the methods mentioned above, the addition of the time-factor to the prediction-model gave a significantly better result (F-test), a positive or negative trend was assumed.

The statistical analyses were performed with STATGRAPHICS Statistical Graphics System version 2.6 .

\section{RESULTS}

Figure 2 gives the water temperature during the annual cycle for all 6 years. Little variability is to be seen in contrast to salinity (Fig. 3).

To ascertain trends (decrease or increase) in this or other parameters, the data were

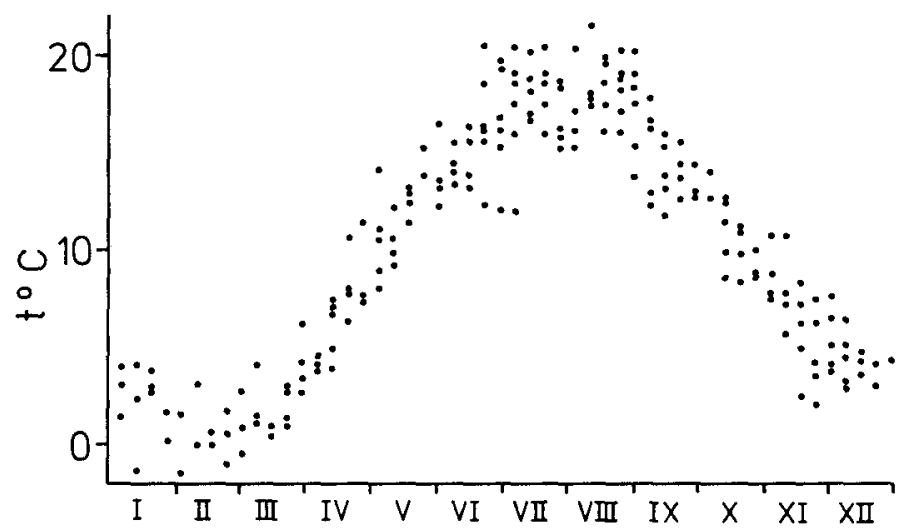

Fig. 2. Water temperature $\left({ }^{\circ} \mathrm{C}\right)$ in the Wadden Sea of Sylt. Annual cycle over six years of investigation 


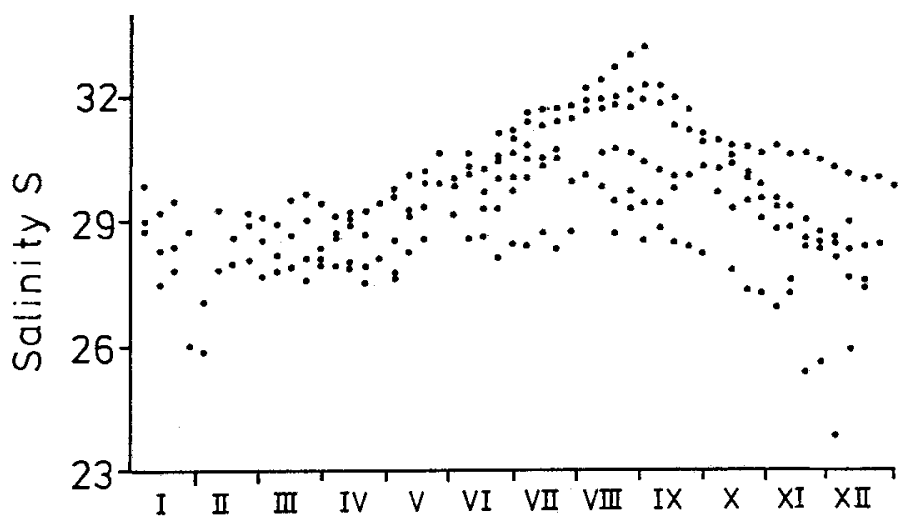

Fig. 3. Salinity $S$ in the Wadden Sea of Sylt. Annual cycle over six years of investigation

grouped according to different "ecological seasons"; these were winter (December $15^{\text {th }}$ to March $15^{\text {th }}$ ), spring (March $15^{\text {th }}$ to May $31^{\text {st }}$ ), nutrient summer-minimum (June $1^{\text {st }}$ to August $31^{\text {st }}$ ) and zooplankton summer/autumn-maximum (June $15^{\text {th }}$ to September $31^{\text {st }}$ ).

Nearly all nutrients measured show a positive trend from 1975 to 1988 , as can be seen in Figures 4 to 7 and Table 1.

$\mathrm{NO}_{2}$ (Fig. 4) shows an increase of at least $300 \%$ from the mid-seventies to 1988 ; the same is true for $\mathrm{NO}_{3}$ (Fig. 5) which shows concentrations of up to $12 \mu$ gat $\mathrm{l}^{-1}$ in summer, values which were reached only in winter 10 years ago.

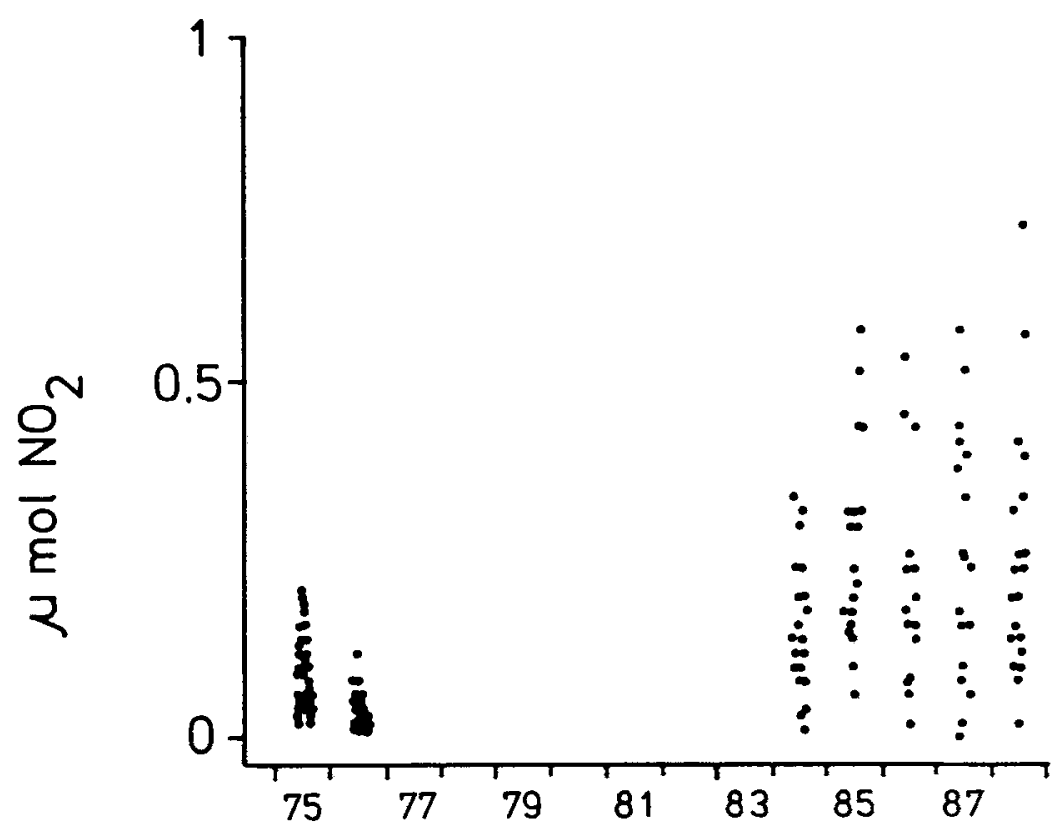

Fig. 4. $\mathrm{NO}_{2}$ in $\mu$ gat $\mathrm{l}^{-1}$ in different years in summer. $\mathrm{X}$-axis $=$ year. $\mathrm{Y}$-axis $=\mathrm{NO}_{2}$ 


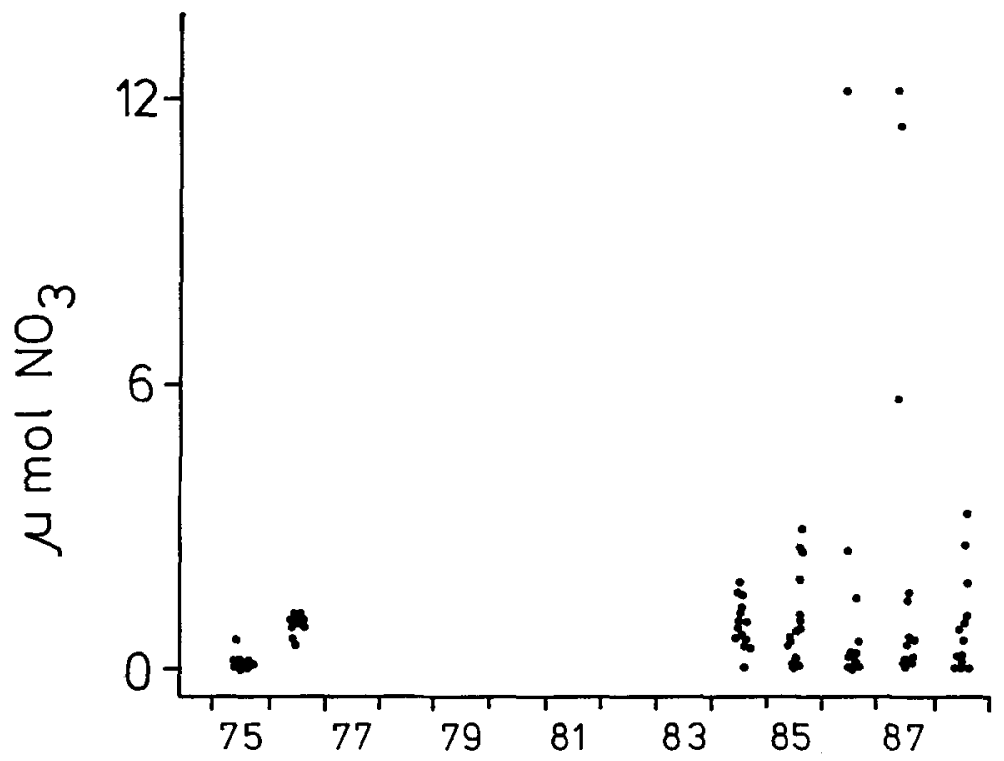

Fig. 5. $\mathrm{NO}_{3}$ in $\mu$ gat $\mathrm{l}^{-1}$ in different years in summer. $\mathrm{X}$-axis $=$ year. $\mathrm{Y}$-axis $=\mathrm{NO}_{3}$

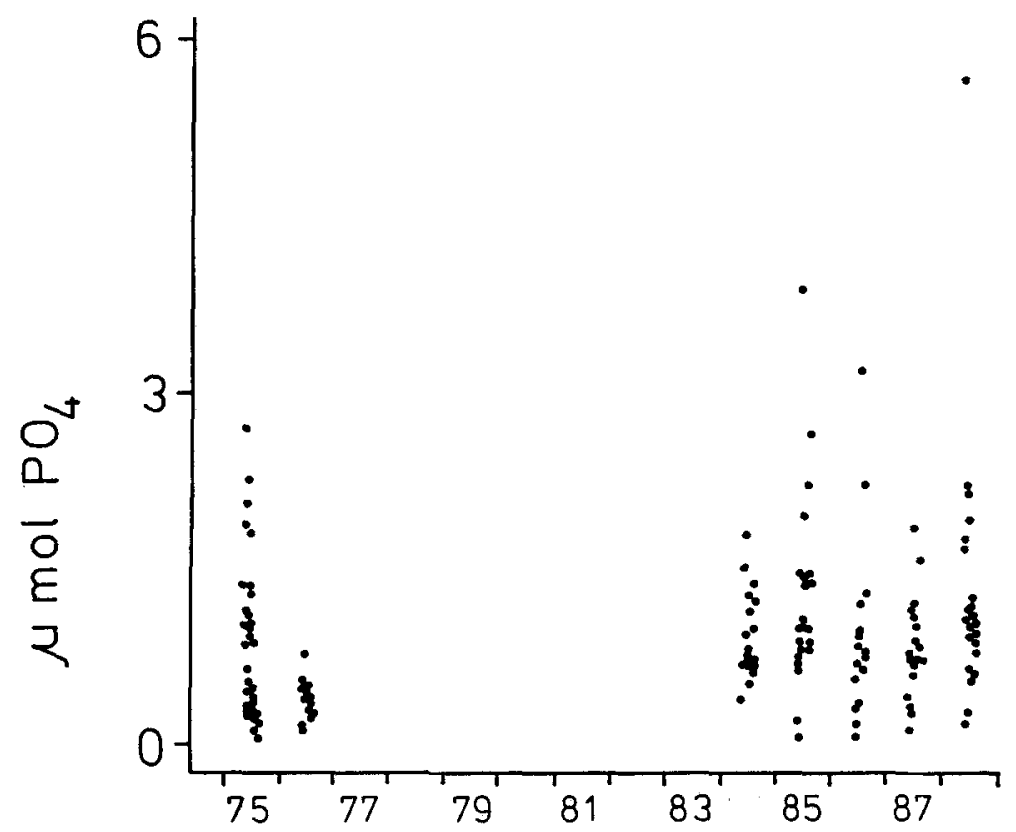

Fig. 6. $\mathrm{PO}_{4}$-concentration in $\mu$ gat $\mathrm{l}^{-1}$ in different years in summer. $\mathrm{X}$-axis $=$ year. $\mathrm{Y}$-axis $=\mathrm{PO}_{4}$ 


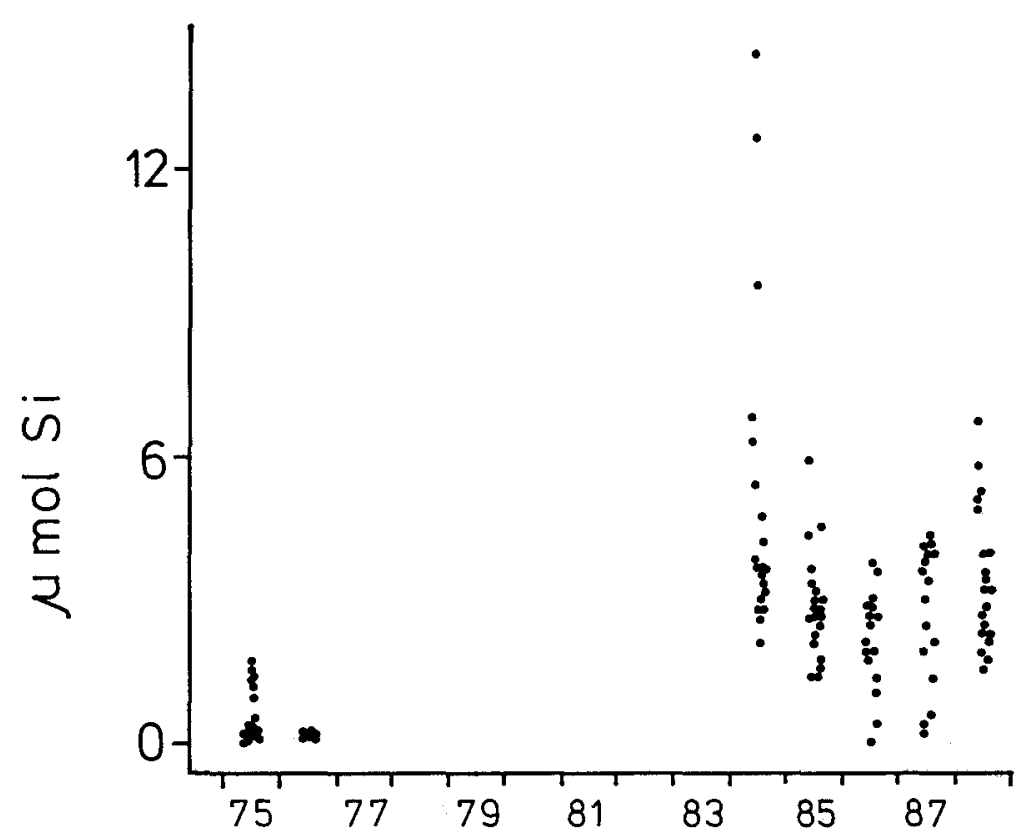

Fig. 7. Si in $\mu$ gat $1^{-1}$ in different years in summer. $\mathrm{X}$-axis $=$ year. $\mathrm{Y}$-axis $=$ Silicate

The changes in $\mathrm{PO}_{4}$-concentration are not so drastic (Fig. 6) as those in silicate (Fig. 7) which shows minima of less than $1 \mu$ gat $1^{-1}$ only on one or two days during the year.

$\mathrm{NH}_{4}$ is the only nutrient measured which showed a negative trend over the years (Fig. 8). This is due to very high values in the mid-seventies and a shift in the relation of $\mathrm{NH}_{4}-\mathrm{NO}_{2}-\mathrm{NO}_{3}$, as can be seen by a comparison of Figures 4,5 and 8 .

For chlorophyll and $\mathrm{pH}$, measurements started as late as 1984 . Nevertheless, significant positive trends could be ascertained for both parameters as can be seen by Table 1 and Figures 9 and 10.

A stepwise variable selection analysis (Table 2) showed (besides the influence of time) the negative relation between chlorophyll-a, $\mathrm{NH}_{4}$ and temperature.

No influencing factors besides time could be ascertained for $\mathrm{pH}$ (Table 2).

$\mathrm{Si}, \mathrm{NH}_{4}$ and $\mathrm{NO}_{3}$ show a significant correlation (negative in $\mathrm{NH}_{4}$ and positive in $\mathrm{Si}$ and $\mathrm{NO}_{3}$ ) with salinity (Table 2), which itself has decreased drastically in summer during the past years (Fig. 11) in close relation with temperature (Table 2).

\section{DISCUSSION}

Up to the mid-seventies, the Wadden Sea of Sylt was an area which was far less eutrophicated than comparable areas in the Dutch Wadden Sea. The Wadden Sea of Sylt had distinct nutrient minima during summer (Hickel, 1989), whereas the Dutch Wadden Sea showed phosphate-maxima during this season (de Jonge \& Postma, 1974).

A decade later $(1984,1985)$, phosphate-concentrations in July-September were 


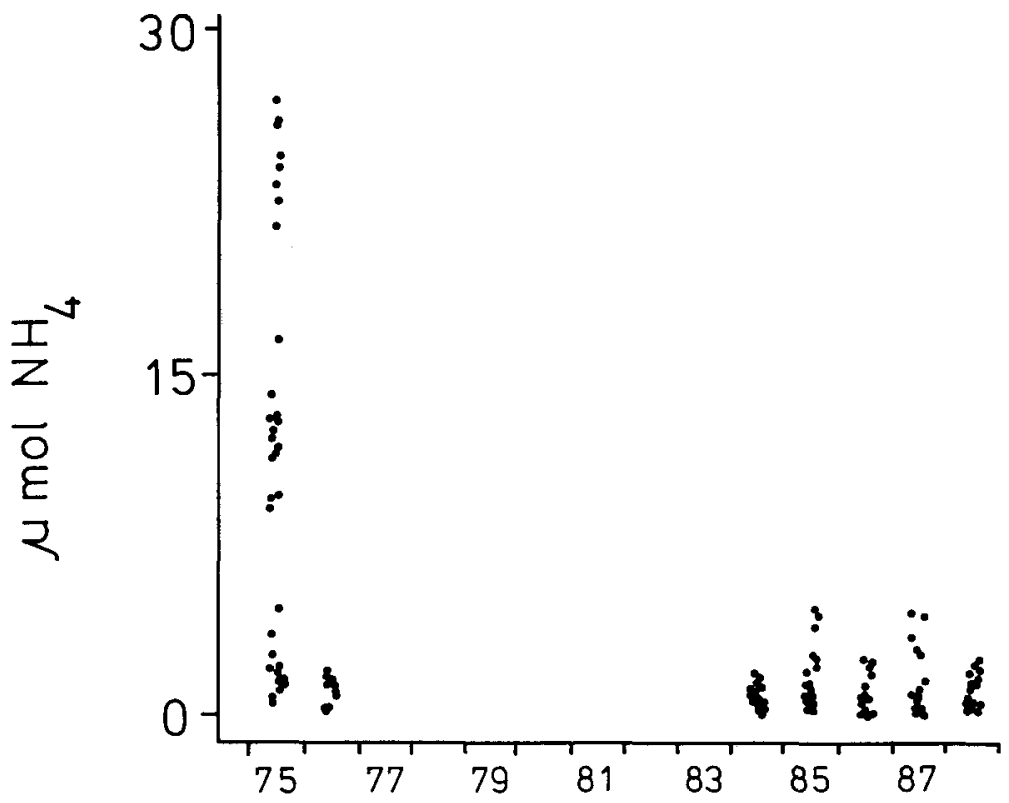

Fig. 8. $\mathrm{NH}_{4}$ in $\mu$ gat $\mathrm{l}^{-1}$ in different years in summer. $\mathrm{X}$-axis $=$ year. $\mathrm{Y}$-axis $=\mathrm{NH}_{4}$

Table 1. $\mathrm{A}=$ Correlation-coefficient for the relation between time and the different parameters, in brackets probability P. B = Spearman-Rank correlation coefficent for the relation between time and the different parameters, in brackets probability $\mathrm{P} . \mathrm{C}=$ Partial correlation coefficient for the relation between time and the different parameters; the influence of temperature and salinity excluded; in brackets probability $P$

\begin{tabular}{|lcrcc|}
\hline Parameter & A & B & C \\
\hline Chlorophyll-a & $0.410(0.00003)$ & $0.353(0.0005)$ & $0.355(<0.001)$ \\
pH & $0.463(0.00001)$ & $0.488(0.0001)$ & $0.265(0.01)$ \\
Salinity & $-0.618(0.00001)$ & $-0.374(0.0001)$ & -- \\
Ammonia & $-0.410(0.00001)$ & $-0.522(0.0001)$ & $-0.511(<0.001)$ \\
Nitrite & $0.492(0.00001)$ & $0.356(0.0001)$ & $0.346(<0.001)$ \\
Nitrate & $0.245(0.00009)$ & $0.250(0.0001)$ & $0.319(<0.001)$ \\
Phosphate & $0.320(0.00001)$ & $0.178(0.0053)$ & $0.196(<0.001)$ \\
Silicate & $0.702(0.00001)$ & $0.633(0.0001)$ & $0.813(<0.001)$ \\
& & & & \\
\hline
\end{tabular}

about four times higher in the Wadden Sea of Sylt, as shown by Hickel (1989) who mentions the possible influence of climatic differences between these years.

An increase of nutrient-concentrations has been shown for the German Bight (Lucht \& Gillbricht, 1978; Radach \& Berg, 1986), not only for phosphate but also for nitrogen, concomitant with a decrease in salinity (Radach \& Berg, 1986) and detectable only during summer. Radach \& Berg mentioned a possible influence of rainfall but could not prove this from their data. 


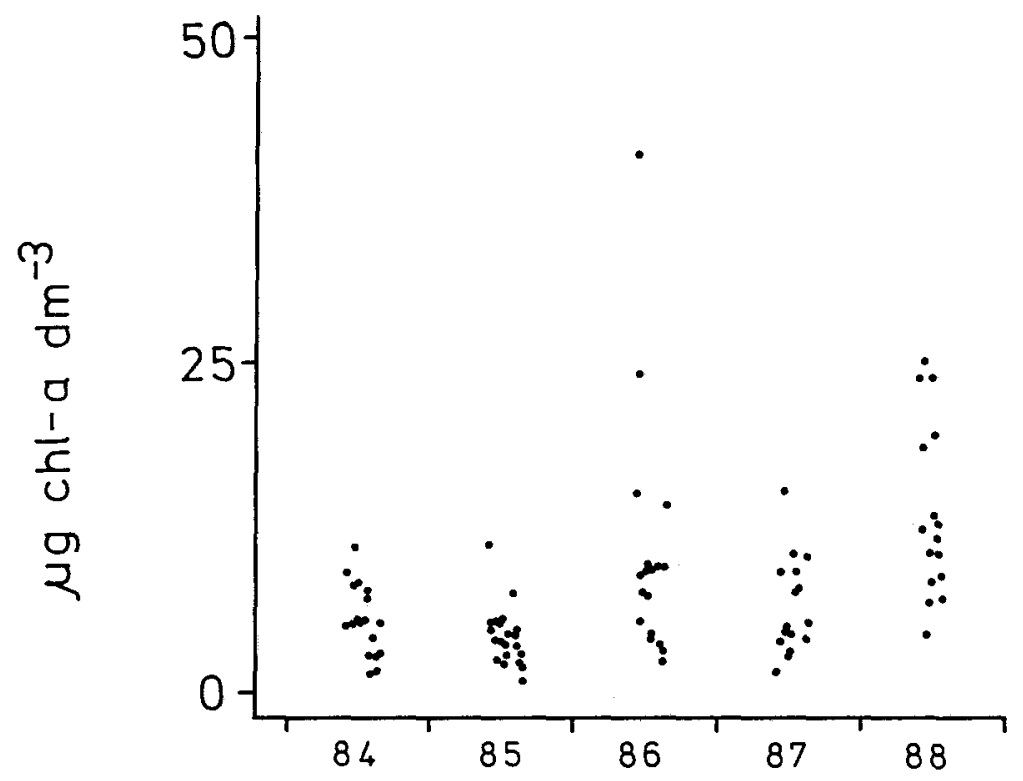

Fig. 9. Chlorophyll-a in $\mu \mathrm{g}^{-1}$ in different years in summer. $\mathrm{X}$-axis $=$ year. $\mathrm{Y}$-axis $=$ Chlorophyll-a

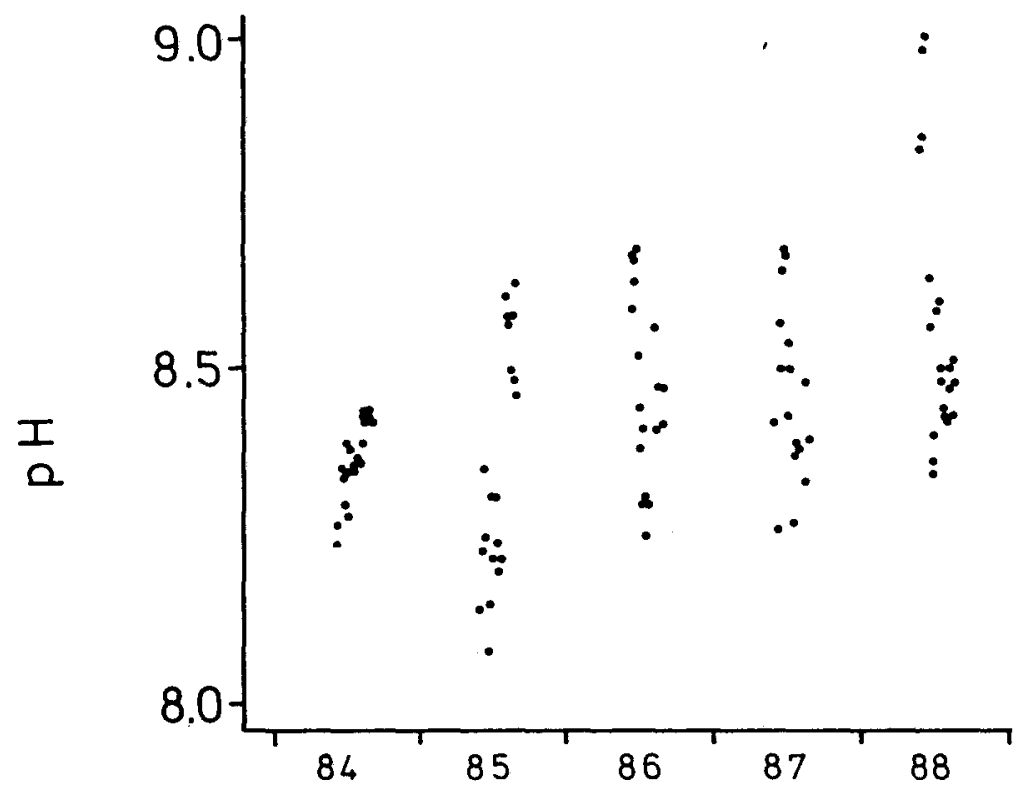

Fig. 10. $\mathrm{pH}$-value in different years in summer. $\mathrm{X}$-axis $=$ year. $\mathrm{Y}$-axis $=\mathrm{pH}$ 
Table 2. List of parameters of significant influence $(\mathrm{P}<0.05)$ on the different parameters measured, derived from a stepwise variable selection. Factor $=$ Parameter of significant influence. $t=$ Regression coefficient/standard error. $\mathrm{sl}=$ significance level for the $\mathrm{t}$-value (the probability that a larger absolute $t$-value would occur if there were no marginal contribution from that parameter)

\begin{tabular}{|llrr|}
\hline Parameter & Factor & $\mathrm{t}$ & $\mathrm{s}$ \\
\hline \multirow{2}{*}{ Chlorophyll-a } & time & 5.294 & $<0.0001$ \\
& temperature & -2.749 & 0.0072 \\
& ammonia & -3.855 & 0.0002 \\
$\mathrm{pH}$ & time & 5.346 & $<0.0001$ \\
Salinity & time & -11.644 & $<0.0001$ \\
& temperature & 6.676 & $<0.0001$ \\
Ammonia & time & -9.406 & 0.0001 \\
& salinity & -3.519 & 0.0005 \\
& rainfall & 3.100 & 0.0022 \\
Nitrite & time & 8.251 & $<0.0001$ \\
& rainfall & 2.359 & 0.0191 \\
Nitrate & time & 4.993 & $<0.0001$ \\
& salinity & 2.331 & 0.0206 \\
Phosphate & time & 5.119 & $<0.0001$ \\
& temperature & -5.940 & $<0.0001$ \\
Silicate & time & 21.780 & $<0.0001$ \\
& temperature & -2.622 & 0.0093 \\
& salinity & 4.185 & $<0.0001$ \\
\hline
\end{tabular}

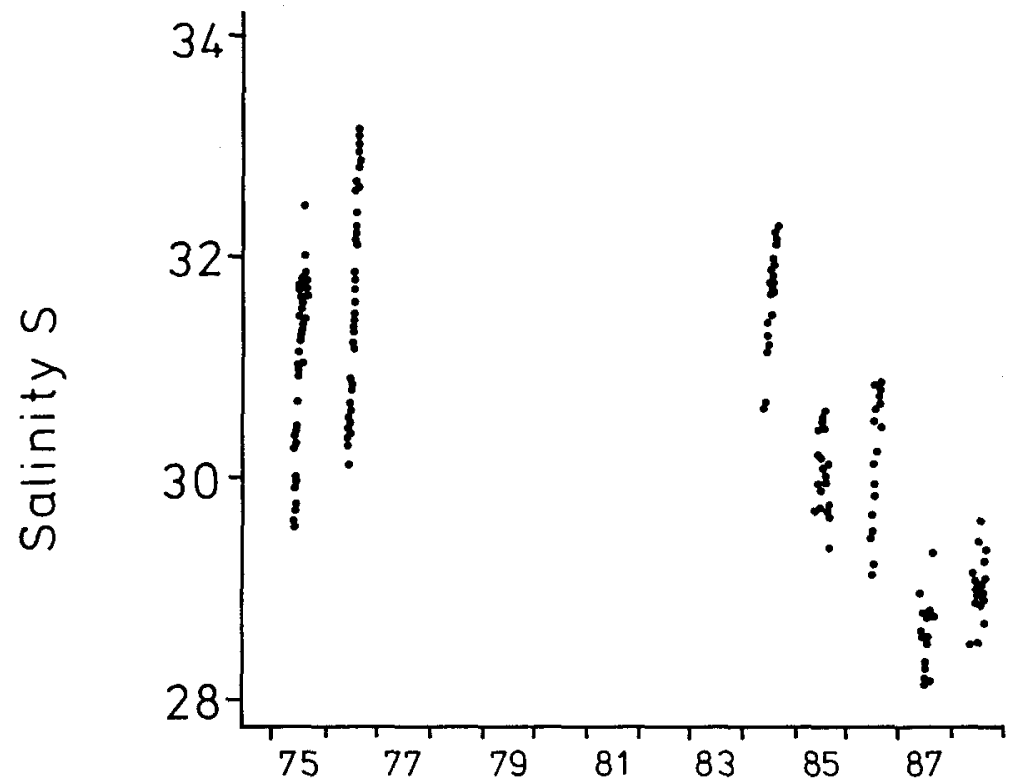

Fig. 11. Salinity $\mathrm{S}$ in different years in summer. $\mathrm{X}$-axis $=$ year. $\mathrm{Y}$-axis $=$ Salinity 
The magnitude of water exchange between the Wadden Sea of Sylt and the German Bight of about $7 \%$ per tide (Hickel, 1980) makes it rather likely that the increase of nutrients in the German Bight would show up in the Wadden Sea as well. This is shown here for $\mathrm{NO}_{2}, \mathrm{NO}_{3}, \mathrm{PO}_{4}$ and $\mathrm{Si}$ and a significant influence of rainfall could be demonstrated during summer months on nitrogen compounds. There are at least two possible explanations.

Measurements by the "Niedersächsische Landesamt für Wasserwirtschaft" (Rost, 1987) have shown that near the island Norderney rain contains about $80 \mu$ gat $\mathrm{N}^{-1}$ (1.6 $\mathrm{mg} \mathrm{NO}_{3}$ and $0.9 \mathrm{mg} \mathrm{NH}_{4}$ ). The Wadden Sea of Sylt extends over an area of about $419 \mathrm{~km}^{2}$. A typical rainy summer can lead to a rainfall of about 201 week ${ }^{-1} \mathrm{~m}^{-2}$, as has been shown by measurements by the "Deutscher Wetterdienst, Wetterstation List". If we assume that rain at Sylt contains as much nitrogen as rain at Norderney, this would lead to a weekly input of $6.7 \times 10^{11} \mu$ gat $N$ for the whole area. The volume of the Wadden Sea is about 8.45 $\times 10^{11}$ liters. Thus rainfall is responsible for an increase of about $0.15 \mu$ gat $\mathrm{N}^{-1}$ day $^{-1}$. This is $20 \%$ to $30 \%$ of the actual nitrogen content in summer and may be a possible explanation for the significant correlation between nitrogen and rainfall.

This relation between nitrogen and rainfall was only true for $\mathrm{NH}_{4}$ and $\mathrm{NO}_{2}$, not for $\mathrm{NO}_{3}$ which was positively related to salinity in contrast to the other nitrogen compounds. Presumably, $\mathrm{NO}_{3}$ enters the Wadden Sea area by tidal water movements; the same holds true for silicate. Radach \& Berg (1986) have shown that Elbe discharge has increased significantly over the last 23 years, as has the nitrogen-concentration in the Helgoland Bight.

Hickel has shown that the Elbe has a significant influence on the Wadden Sea of Sylt which is 6 times as high as the influence by local freshwater inflow. Thus, an influence by increased Elbe discharge with its nutrient-load on the Wadden Sea is very likely.

The significant negative correlation between phytoplankton (chlorophyll-a) and $\mathrm{NH}_{4}$ is thought to reflect the uptake of nitrogen during algal growth; $\mathrm{Si}$ - and $\mathrm{PO}_{4}$-concentrations are too high to be influenced by the small amount of phytoplankton compared to the benthic microflora.

What can clearly be seen from the present paper is the strong variability of the parameters measured within the Wadden Sea area. Only during the season of least variability (summer), could a trend in the concentrations be verified for some parameters. Longer time series are needed to prove trends during other seasons and for other parameters.

On the other hand, it seems somewhat alarming that, even in areas of great natural variability, a positive trend in nutrient concentration could be found.

Acknowledgements. Thanks are due to the staff of the Wetterstation List of the Deutsche Wetterdienst for meteorological data, to C. Reineke and the crew of F. K. Mya for technical assistance, and to $K$. Reise for valuable comments on the paper.

\section{LITERATURE CITED}

Grasshoff, K., 1976. Methods of seawater analysis. Verl. Chemie, Weinheim, 317 pp.

Hickel, W., 1975. The mesozooplankton of the Wadden Sea of Sylt (North Sea). - Helgoländer Meeresunters. 27, 254-262. 
Hickel, W., 1980. The influence of Elbe River water on the Wadden Sea of Sylt (German Bight, North Sea). - Dt. hydrogr. Z. 33, 43-52.

Hickel, W., 1983. Seston in the Wadden Sea of Sylt (German Bight, North Sea). - Publ. Ser. Neth. Inst. Sea Res. 10-1984, 113-131.

Hickel, W., 1989. Inorganic micronutrients in relation to phytoplankton and the eutrophication in the Wadden Sea of Sylt (German Bight, North Sea). - Proceedings of the $21^{\text {st }}$ European Marine Biology Synposium, Gdansk, Poland (in press).

Jonge, V. N. de \& Postma, H., 1974. Phosphorous compounds in the Dutch Wadden Sea. - Neth. J. Sea Res. 8, 139-153.

Lucht, F. \& Gillbricht, M., 1978. Long-term observations on nutrient contents near Helgoland in relation to nutrient input of the river Elbe. - Rapp. P.-v. Réun. Cons. int. Explor. Mer 172, 358-360.

Martens, P., 1980. Beiträge zum Mesozooplankton des Nordsylter Wattenmeers. - Helgoländer Meeresunters. 34, 41-53.

Martens, P., 1981. On the Acartia species of the northern Wadden Sea of Sylt. - Kieler Meeresforsch. (Sonderh.) 5, 153-163.

Martens, P., 1982. Zur Biologie des Planktons des Königshafens (Nordsylter Wattenmeer). - Helgoländer Meeresunters. 35, 243-251.

Martens, P., 1986a. Short-term fluctuations in hydrographic parameters during a declining Phaeocystis-bloom in May 1984. - Annls biol., Copenh. 41, 47-49.

Martens, P., 1986b. On the hydrography of the north Frisian Wadden Sea in June 1984. - Annls biol. Copenh. 41, 46-47.

Radach, G. \& Berg, J., 1986. Trends in den Konzentrationen der Nährstoffe und des Phytoplanktons in der Helgoländer Bucht (Helgoland Reede Daten). - Ber. Biol. Anst. Helgoland 2, 1-63.

Rost, J., 1987. Stoffeintrag durch Niederschläge. In: Umwelt Vorsorge Nordsee. Ed. by W. Remmers. Niedersächs. Umweltmin., Hannover, $366 \mathrm{pp}$.

STSC, 1987. STATGRAPHICS Statistical Graphics System. Ed. by STSC Incorporated. Rockville. 